\title{
Classification of acetic acid bacteria and their acid resistant mechanism
}

\author{
Xiaoman Qiu ${ }^{1,2}$, Yao Zhang ${ }^{1,2}$ and Housheng Hong ${ }^{1,2^{*}}$ (1)
}

\begin{abstract}
Acetic acid bacteria (AAB) are obligate aerobic Gram-negative bacteria that are commonly used in vinegar fermentation because of their strong capacity for ethanol oxidation and acetic acid synthesis as well as their acid resistance. However, low biomass and low production rate due to acid stress are still major challenges that must be overcome in industrial processes. Although acid resistance in $A A B$ is important to the production of high acidity vinegar, the acid resistance mechanisms of $A A B$ have yet to be fully elucidated. In this study, we discuss the classification of $A A B$ species and their metabolic processes and review potential acid resistance factors and acid resistance mechanisms in various strains. In addition, we analyze the quorum sensing systems of Komagataeibacter and Gluconacetobacter to provide new ideas for investigation of acid resistance mechanisms in AAB in the form of signaling pathways. The results presented herein will serve as an important reference for selective breeding of high acid resistance AAB and optimization of acetic acid fermentation processes.
\end{abstract}

Keywords: Acetic acid bacteria, Genus and species classification, Metabolic regulatory, Acid resistance mechanism, Quorum sensing, Signaling pathways

\section{Key points}

- Summarize the current classification of AAB (19 genera and 92 species) in detail for the first time;

- Investigate the acid resistance mechanism in $A A B$ systematically and comprehensively;

- Explain the acid resistance mechanism from the new perspective of signal pathways.

\section{Introduction}

Acetic acid bacteria (AAB), which are also known as Acetobacter sp., are obligate aerobic Gram-negative bacteria found in the Alphaproteobacteria class, Rhodospirillales order, and Acetobacteraceae family (Kersters 2006). $A A B$ are often found in warm and humid regions, in fruits, flowers, fruit fly guts, and some fermented foods

\footnotetext{
*Correspondence: hhs@njtech.edu.cn

${ }^{1}$ College of Biotechnology and Pharmaceutical Engineering, Nanjing Tech University, No. 30, Puzhu Road, Nanjing 211800, China

Full list of author information is available at the end of the article
}

(Chouaia et al. 2014; Kersters et al. 2006; Sengun and Karabiyikli 2011; Soemphol et al. 2011; Trček and Barja 2015). When compared with other bacteria, AAB show high variability (Azuma et al. 2009). Therefore, the taxonomy of $\mathrm{AAB}$ has undergone a long process of development that started with an initial phenotypic classification and continued as the polyphasic classification approach became available. Polyphasic classification mainly includes phenotypic, chemical, and genetic classification methods (Greenberg et al. 2006; Lisdiyanti et al. 2006). In the past few decades, the development of molecular biology techniques has further refined the biological classification of AAB. However, as things stand at present, no researchers have summarized the newly discovered specific genus and species classification of AAB systematically, except for a 2008 article that only summarized the 10 genus and 45 species (Cleenwerck and Vos 2008), which is a major focus of our article.

Major metabolic pathways in $\mathrm{AAB}$ include the ethanol oxidation respiratory chain pathway, tricarboxylic acid cycle pathway, pyruvate metabolic pathway, and pentose
Springer Open

(c) The Author(s) 2021. This article is licensed under a Creative Commons Attribution 4.0 International License, which permits use, sharing, adaptation, distribution and reproduction in any medium or format, as long as you give appropriate credit to the original author(s) and the source, provide a link to the Creative Commons licence, and indicate if changes were made. The images or other third party material in this article are included in the article's Creative Commons licence, unless indicated otherwise in a credit line to the material. If material is not included in the article's Creative Commons licence and your intended use is not permitted by statutory regulation or exceeds the permitted use, you will need to obtain permission directly from the copyright holder. To view a copy of this licence, visit http://creativeco mmons.org/licenses/by/4.0/. 
phosphate pathway. Among these, the most significant reaction is the incomplete oxidation of sugars, alcohols, or sugar alcohols into aldehydes, ketones, and organic acids (Sengun 2017). The greatest strength of AAB is their ability to use less biomass to produce large amounts of acetic acid compared to other bacterias that produce organic acids (López-Garzón and Straathof 2014); therefore, they are important industrial microorganisms that are widely used in the production of vinegar and fruit vinegar, gluconic acid products, and development of biofuel cells (Lynch et al. 2019; Misra et al. 2012; Sainz et al. 2016).

The presence of acetic acid in vinegar products makes $\mathrm{AAB}$ fermentation unique (Zhang et al. 2016; Zheng et al. 2018). Specifically, acetic acid changes the flavor of vinegar and increases the survival advantages of $A A B$ (Lynch et al. 2019; Hong 2016, 2017); however, acetic acid accumulation causes acid stress that inhibits AAB growth (Trček et al. 2015). During fermentation, the large number of dehydrogenases on the cell membrane of $\mathrm{AAB}$ causes the incomplete oxidation of many carbon sources into acetic acid (Matsushita et al. 2016). Because of the incomplete glycolysis, the main energy sources for maintaining cellular homeostasis are from the respiratory chain, tricarboxylic acid cycle, and pentose phosphate pathway (Illeghems et al. 2013). Resistance towards highly acidic environments requires large amounts of energy, which severely limits cell growth. As a result, $\mathrm{AAB}$ with high acid resistance can increase acetic acid productivity and conversion rate, thereby increasing the bioconversion efficiency of acetic acid. Hence, elucidation of acid resistance mechanisms can provide important guidance for the selective breeding of acetic acid-producing bacteria and bioconversion of high acidity vinegar.

We found that most researchers only wrote part of the acid resistance mechanism of $\mathrm{AAB}$ and none of them described the relationship between the quorum sensing and acid resistance mechanism of AAB. In this review, we discuss the specific classification of $A A B$ for the first time and its metabolic pathways before systematically and comprehensively summarizing the latest studies on acid resistance in AAB. In addition, we analyze the quorum sensing systems of Komagataeibacter and Gluconacetobacter to elucidate acid resistance mechanisms in $\mathrm{AAB}$ from a new perspective of signal pathways.

\section{Overview of $A A B$ and its taxonomy}

There are many types of $\mathrm{AAB}$, among which the first genus, Acetobacter, was first proposed and described by Beijerinck in 1898 (Beijerinck 1898). Subsequently, four major genera (Acetobacter, Gluconobaeter, Gluconacetobacter, and Komagataeibacter) were confirmed based on their ethanol oxidation capabilities and the type of respiratory chain coenzyme they contained (Asai 1935; Yamada et al. 1983, 2012). With the development of polyphasic classification techniques, new genera and species have been continuously found (Cleenwerck 2008), and 19 genera and 92 species of $\mathrm{AAB}$ have been identified to date (Table 1). AAB are mainly used in the industrial production of vinegars and fruit vinegar beverages, with Acetobacter and Komagataeibacter being primarily used in vinegar making (Kanchanarach et al. 2010; Wu et al. 2012).

\section{Acetobacter}

Acetobacter uses two membrane-bound enzymes (alcohol dehydrogenase $(\mathrm{ADH})$ and acetaldehyde dehydrogenase (ALDH)) to oxidize ethanol to acetic acid during respiration, after which it further oxidizes acetic acid and lactic acid to carbon dioxide and water. However, Acetobacter are unable to utilize sugar alcohols such as glycerol, sorbitol, and mannitol to produce acetic acid. The respiratory chain coenzyme $(\mathrm{CoQ})$ used by Acetobacter is Q9 (Kersters et al. 2006).

At present, the main strains used in industrial production of acetic acid in China are A. pasteurianus Zhongke AS1.41 and Huniang 1.01 (Chen et al. 2017), which are relatively uniform. Damage will occur in Acetobacter strains when the acetic acid concentration reaches $7-8 \%$; therefore, these strains are mainly used in conventional surface production of vinegar and the final acid concentration usually does not exceed $8 \%$, with a maximum acidity of 9-10\% (Andrés-Barrao et al. 2016). A recent study reported that $A$. pasteurianus could produce acetic acid in a two-stage aeration protocol with a maximum acidity of 9.33\% (Qi et al. 2014). In addition, strains isolated from traditional vinegars such as Chinese grain vinegar, Japanese Komesu and Kurosu vinegars, and South Korean black raspberry vinegar are mainly $A$. pasteurianus (Nanda et al. 2001; Song et al. 2016; Wang 2016).

\section{Komagataeibacter}

Komagataeibacter can oxidize ethanol to acetic acid and oxidize acetic acid to carbon dioxide and water (Yamada et al. 2012). The respiratory chain CoQ used by Komagataeibacter is Q10 (Kersters et al. 2006). Members of this genus are characterized by an absence of flagella and inability to produce brown compounds. In addition, some strains can produce cellulose, show an inability to produce 2,5-diketo-D-gluconate, are able to produce dihydroxyacetone from glycerol, and can oxidize glucose, galactose, xylose, arabinoside, and ethanol to produce organic acids.

Komagataeibacter strains, which can resist 15-20\% acetic acid, are mainly used to produce fruit vinegar and alcoholic vinegar in liquid-state deep fermentation in 
Table 1 Current classification of the Acetobacteraceae (19 genera, 92 species)

\begin{tabular}{|c|c|c|c|c|c|}
\hline Species $^{a}$ & $\mathrm{DNA} G+\mathrm{C}(\mathrm{mol} \%)^{\mathrm{b}}$ & References & Species $^{a}$ & DNA G + C (mol\% $)^{b}$ & References \\
\hline Acetobacter aceti & $56.4-58.3$ & Lisdiyanti et al. (2000) & $\begin{array}{l}\text { Gluconacetobacter diazo- } \\
\text { trophicus }\end{array}$ & $61.0-63.0$ & Yamada et al. (1997) \\
\hline Acetobacter ascendens & $53.2-53.3$ & Kim et al. (2018) & $\begin{array}{l}\text { Gluconacetobacter } \\
\text { entanii }\end{array}$ & 58.0 & Lisdiyanti et al. (2006) \\
\hline Acetobacter cerevisiae & $56.0-57.6$ & lino et al. (2012) & $\begin{array}{l}\text { Gluconacetobacter } \\
\text { johannae }\end{array}$ & $57.96-67.5$ & Nishijima et al. (2013) \\
\hline $\begin{array}{l}\text { Acetobacter cibinon- } \\
\text { gensisc }\end{array}$ & $53.8-54.5$ & Lisdiyanti et al. (2001) & $\begin{array}{l}\text { Gluconacetobacter } \\
\text { liquefaciens }\end{array}$ & $63.5-66.9$ & Yamada et al. (1997) \\
\hline Acetobacter estunensis & $59.2-60.2$ & Lisdiyanti et al. (2000) & $\begin{array}{l}\text { Gluconacetobacter } \\
\text { sacchari }\end{array}$ & $62.1-67.3$ & Franke et al. (1999) \\
\hline Acetobacter fabarum & $56.8-58$ & lino et al. (2012) & $\begin{array}{l}\text { Gluconacetobacter taka- } \\
\text { matsuzukensis }\end{array}$ & 66.6 & Nishijima et al. (2013) \\
\hline Acetobacter farinalis & $56.3-56.5$ & lino et al. (2012) & $\begin{array}{l}\text { Gluconacetobacter } \\
\text { tumulicola }\end{array}$ & 64.7 & Nishijima et al. (2013) \\
\hline Acetobacterghanensis & $56.9-57.3$ & lino et al. (2012) & $\begin{array}{l}\text { Gluconacetobacter } \\
\text { tumulisoli }\end{array}$ & 66.5 & Nishijima et al. (2013) \\
\hline Acetobacter indonesiensis & $53.7-55.0$ & Lisdiyanti et al. (2000) & Gluconobacter albidusf & $58.1-60.0$ & Malimas et al. (2007) \\
\hline Acetobacter lambici & 56.2 & Spitaels et al. (2013) & Gluconobacter cerinus & $54-56$ & Malimas et al. (2007) \\
\hline Acetobacter lovaniensis & $57.1-58.9$ & lino et al. (2012) & Gluconobacter frateurii & $57.5-57.7$ & Malimas et al. (2007) \\
\hline Acetobacter malorum & 57.2 & lino et al. (2012) & Gluconobacter japonicus & 56.4 & Malimas et al. (2009) \\
\hline Acetobacter musti & 58 & Ferrer et al. (2016) & $\begin{array}{l}\text { Gluconobacter kan- } \\
\text { chanaburiensis }\end{array}$ & 59.5 & Tanasupawat et al. (2011) \\
\hline $\begin{array}{l}\text { Acetobacter nitrogenifi- } \\
\text { gens }\end{array}$ & 64.1 & $\begin{array}{l}\text { Dutta and Gachhui } \\
\text { (2006) }\end{array}$ & Gluconobacter kondonii & 59.8 & Malimas et al. (2007) \\
\hline Acetobacter oeni & 58.1 & Silva et al. (2006) & Gluconobacter nephelii & $57.2-57.6$ & Kommanee et al. (2010) \\
\hline Acetobacter okinawensis & $59.2-59.4$ & lino et al. (2012) & Gluconobacter oxydans & $60.3-63.5$ & Malimas et al. (2007) \\
\hline Acetobacter orientalis & $52.0-52.8$ & Lisdiyanti et al. (2001) & Gluconobacter roseus & 60.5 & Tanasupawat et al. (2011) \\
\hline Acetobacter orleanensis & $55.7-58.9$ & Lisdiyanti et al. (2000) & Gluconobacter sphaericus & 59.5 & Tanasupawat et al. (2011) \\
\hline Acetobacter oryzoeni & 53.1 & Baek et al. (2020) & $\begin{array}{l}\text { Gluconobacter thailan- } \\
\text { dicus }\end{array}$ & $55.3-56.3$ & Malimas et al. (2007) \\
\hline $\begin{array}{l}\text { Acetobacter oryzifermen- } \\
\text { tans }\end{array}$ & 52.4 & Kim et al. (2018) & $\begin{array}{l}\text { Gluconobacter wanch- } \\
\text { erniae }\end{array}$ & 56.6 & Tanasupawat et al. (2011) \\
\hline Acetobacter pasteurianus & $51.8-54.3$ & Lisdiyanti et al. (2000) & Gluconobacter uchimurae & $60.4-60.6$ & Tanasupawat et al. (2011) \\
\hline Acetobacter papayae & $60.5-60.7$ & lino et al. (2012) & Granulibacter bethensis & 59 & $\begin{array}{l}\text { Ramírez-Bahena et al. } \\
\text { (2013) }\end{array}$ \\
\hline Acetobacter peroxydans & $59.7-60.7$ & lino et al. (2012) & $\begin{array}{l}\text { Komagataeibacter } \\
\text { europaeus }\end{array}$ & $56-58$ & Yamada et al. (1997) \\
\hline Acetobacter persicus & $58.7-58.9$ & lino et al. (2012) & $\begin{array}{l}\text { Komagataeibacter } \\
\text { hansenii }\end{array}$ & $58-59$ & Yamada et al. (1997) \\
\hline Acetobacter pomorum & 52.1 & Sokollek et al. (1998) & $\begin{array}{l}\text { Komagataeibacter inter- } \\
\text { medius }\end{array}$ & 61.6 & Yamada et al. (2000) \\
\hline Acetobacter senegalensis & 56 & Ndoye et al. (2007) & $\begin{array}{l}\text { Komagataeibacter } \\
\text { kakiaceti }\end{array}$ & 62.10 & Škraban et al. (2018) \\
\hline Acetobacter sicerae & 58.3 & Li et al. (2014) & $\begin{array}{l}\text { Komagataeibacter kom- } \\
\text { buchae }\end{array}$ & 59.63 & Škraban et al. (2018) \\
\hline Acetobacter syzygii & $54.3-55.4$ & lino et al. (2012) & $\begin{array}{l}\text { Komagataeibacter } \\
\text { maltaceti }\end{array}$ & $62.5-63.3$ & Slapšak et al. (2013) \\
\hline Acetobacter tropicalis & $55.2-56.2$ & Lisdiyanti et al. (2000) & $\begin{array}{l}\text { Komagataeibacter medel- } \\
\text { linensis }\end{array}$ & $58-60.7$ & Castro et al. (2013) \\
\hline Acidomonas methanolica & $63-66$ & $\begin{array}{l}\text { Ramírez-Bahena et al. } \\
\text { (2013) }\end{array}$ & $\begin{array}{l}\text { Komagataeibacter } \\
\text { nataicola }\end{array}$ & 62 & Lisdiyanti et al. (2006) \\
\hline $\begin{array}{l}\text { Ameyamaea chiang- } \\
\text { maiensis }\end{array}$ & $66-66.1$ & Yukphan et al. (2009) & $\begin{array}{l}\text { Komagataeibacter } \\
\text { oboediens }\end{array}$ & 59.9 & Yamada et al. (2000) \\
\hline Asaia astilbes & $58.8-59.4$ & Suzuki et al. (2010) & $\begin{array}{l}\text { Komagataeibacter } \\
\text { pomaceti }\end{array}$ & $62.53-62.75$ & Škraban et al. (2018) \\
\hline
\end{tabular}


Table 1 (continued)

\begin{tabular}{|c|c|c|c|c|c|}
\hline Species $^{a}$ & DNA G + C $(\mathrm{mol} \%)^{b}$ & References & Species $^{a}$ & DNA G + C (mol\% $)^{b}$ & References \\
\hline Asaia bogorensis & $59.3-61.0$ & Yamada et al. (2000) & $\begin{array}{l}\text { Komagataeibacter } \\
\text { rhaeticus }\end{array}$ & 63.4 & Dellaglio et al. (2005) \\
\hline Asaia krungthepensis & $60.2-60.5$ & Yukphan et al. (2004) & $\begin{array}{l}\text { Komagataeibacter } \\
\text { swingsii }\end{array}$ & 61.7 & Dellaglio et al. (2005) \\
\hline Asaia lannaensis & $60.8-60.9$ & Malimas et al. (2008) & $\begin{array}{l}\text { Komagataeibacter sucro- } \\
\text { fermentans }\end{array}$ & 62.33 & Škraban et al. (2018) \\
\hline Asaia platycodi & $60.0-60.1$ & Suzuki et al. (2010) & $\begin{array}{l}\text { Komagataeibactersac- } \\
\text { charivorans }\end{array}$ & 61 & Lisdiyanti et al. (2006) \\
\hline Asaia prunellae & $58.9-59.3$ & Suzuki et al. (2010) & Komagataeibacter xylinus & $59.4-63.2$ & Yamada et al. (1997) \\
\hline Asaia siamensis & $58.6-59.7$ & Katsura et al. (2001) & Kozakia baliensis & $56.8-57.2$ & $\begin{array}{l}\text { Ramírez-Bahena et al. } \\
\text { (2013) }\end{array}$ \\
\hline Asaia spathodeae & $59.7-59.8$ & Kommanee et al. (2010) & $\begin{array}{l}\text { Neoasaia chiangmaien- } \\
\quad \text { sisg }\end{array}$ & 63.1 & $\begin{array}{l}\text { Ramírez-Bahena et al. } \\
\text { (2013) }\end{array}$ \\
\hline Bombella apis & 59.5 & Yun et al. (2017) & $\begin{array}{l}\text { Neokomagataea } \\
\text { tanensis }\end{array}$ & 51.2 & Yukphan et al. (2011) \\
\hline $\begin{array}{l}\text { Commensalibacter } \\
\text { intestini }\end{array}$ & 36.85 & Kim et al. (2012) & $\begin{array}{l}\text { Neokomagataea thai- } \\
\text { landica }\end{array}$ & 56.8 & Yukphan et al. (2011) \\
\hline $\begin{array}{l}\text { Commensalibacter } \\
\text { papalotli }\end{array}$ & 36.66 & $\begin{array}{l}\text { Servin-Garciduenas et al. } \\
\text { (2014) }\end{array}$ & $\begin{array}{l}\text { Nguyenibacter vanlan- } \\
\text { gensis }\end{array}$ & $59.3-61.0$ & Vu et al. (2013) \\
\hline Endobacter medicaginis & 60.3 & $\begin{array}{l}\text { Ramírez-Bahena et al. } \\
\text { (2013) }\end{array}$ & Saccharibacter floricola & $51.9-52.3$ & Jojima et al. (2004) \\
\hline $\begin{array}{l}\text { Gluconacetobacter } \\
\text { aggeris }\end{array}$ & 65.4 & Nishijima et al. (2013) & $\begin{array}{l}\text { Swaminathania salitol- } \\
\text { erans }\end{array}$ & $57.6-59.9$ & $\begin{array}{l}\text { Ramírez-Bahena et al. } \\
\text { (2013) }\end{array}$ \\
\hline $\begin{array}{l}\text { Gluconacetobacter } \\
\text { asukensis }\end{array}$ & $65.2-65.4$ & Nishijima et al. (2013) & Swingsia samuiensis & $59.3-61.0$ & Malimas et al. (2013) \\
\hline $\begin{array}{l}\text { Gluconacetobacter azoto- } \\
\text { captans }\end{array}$ & $64.01-65.7$ & Nishijima et al. (2013) & $\begin{array}{l}\text { Tanticharoenia sakaer- } \\
\text { atensis }\end{array}$ & $64.5-65.6$ & Yukphan et al. 2008) \\
\hline
\end{tabular}

a The type species of each genus is indicated in bold

b Data taken from literature (for Acetobacter: lino et al. 2012; Kim et al. 2018; Lisdiyanti et al. 2000, 2001; Malimas et al. 2007, 2008; Ramírez-Bahena et al. 2013; Suzuki et al. 2010; Tanasupawat et al. 2001, 2011; Yamada et al. 2000; Yukphan et al. 2004; for Acidomonas: Yamada et al. 1997; for Ameyamaea: Kommanee et al. 2010; for Asaia: Kim et al. 2012; Servin-Garciduenas et al. 2014; Škraban et al. 2018; Slapšak et al. 2013; Spitaels et al. 2013; Yun et al. 2017; for Bombella, Commensalibacter, Endobacter, Gluconobacter, Gluconacetobacter, Granulibacter, Komagataeibacter, Kozakia, Nguyenibacter, Neoasaia, Neokomagataea, Saccharibacter, Swaminathania, Swingsia, Tanticharoenia: from reference in table above)

Europe (Andrés-Barrao et al. 2016). Several Komagataeibacter strains have been isolated during high acidity vinegar production, including K. europaeus, K. intermedius, K. oboediens, and K. hansenii (Xia et al. 2016; Sievers et al. 1992; Trček et al. 2000; Yamada et al. 2012).

\section{Analysis of metabolic pathways in $A A B$}

Major metabolic pathways in $A A B$ include the ethanol oxidation respiratory chain pathway, tricarboxylic acid cycle pathway, pyruvate metabolic pathway, and pentose phosphate pathway (Fig. 1). AAB possess unique oxidation capabilities, of which the classic reaction is incomplete oxidation of ethanol into acetic acid, which is used to produce vinegar.

This ethanol metabolic pathway consists of a two-step reaction (Mas et al. 2014; Tesfaye et al. 2002) (Fig. 1a). $\mathrm{ADH}$ present on the outer cell membrane in the respiratory chain facing the periplasmic space binds to pyrroloquinoline quinone (PQQ) to oxidize ethanol to acetaldehyde. Next, acetaldehyde is further oxidized by
ALDH into acetic acid (Saichana et al. 2015). The entire process is an exothermic reaction, and oxidation of $1 \mathrm{~mol}$ of ethanol into acetic acid releases $493 \mathrm{~kJ}$ of heat (Matsutani et al. 2013).

In addition, $\mathrm{AAB}$ possess NAD-ADH and NADPALDH, which use $\mathrm{NAD}^{+} / \mathrm{NADP}^{+}$as coenzymes. NADADH and NADP-ALDH are located in the cytoplasm and can convert ethanol that enters the cell into acetic acid before converting acetic acid into acetyl-CoA to enter the tricarboxylic acid cycle for complete oxidation into carbon dioxide and water. PQQ-ADH and ALDH mainly participate in ethanol oxidative fermentation. During acetic acid synthesis, the activities of NAD-ADH and NADP-ALDH are completely inhibited (Chinnawirotpisan et al. 2003; Gullo et al. 2014; Yakushi and Matsushita 2010).

In addition to metabolic pathways for acetic acid synthesis, there are also many types of oxidation processes in AAB (Saichana et al. 2015). These reactions primarily occur on the cell membrane and are catalyzed by 


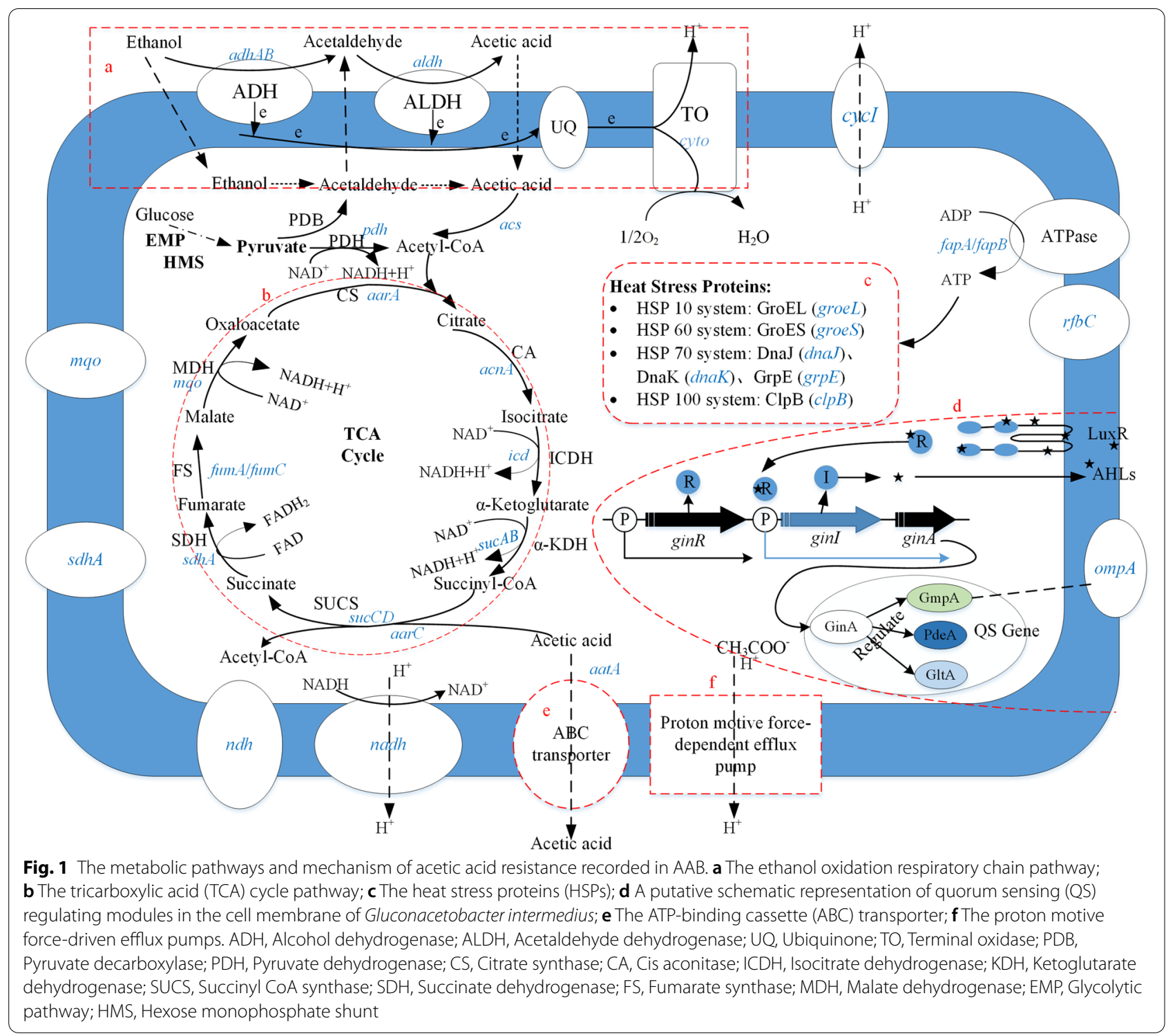

pyrroloquinoline quinone-bound dehydrogenase. In these reactions, substrates undergo incomplete oxidation to be converted into corresponding products that are released into the environment. Electrons released by different dehydrogenases are transferred to the terminal oxidase under the assistance of $\mathrm{CoQ}$, which binds to oxygen (the final electron acceptor) to synthesize water. However, under hypoxic conditions other compounds can be used as the final electron acceptor to ensure bacterial growth (Drysdale and Fleet 1988). For example, acetaldehyde is used as the final acceptor in alcoholic vinegar fermentation, but microorganisms can only maintain physiological activity under this state and are unable to conduct acetic acid anabolism (Millet and LonvaudFunel 2000). Nevertheless, certain AAB are able to use quinones or vat dyes under hypoxic conditions, enabling respiration to continue (Qi et al. 2013).

Most metabolic pathways in $\mathrm{AAB}$ require oxygen, and oxygen consumption is directly proportional to acetic acid production. Hypoxia causes production capacities to rapidly decrease, and may even cause bacteria to die (Ory et al. 2002, 2004). Therefore, sufficient oxygen must be provided during fermentation.

\section{Acid resistance mechanisms in $A A B$}

Acetic acid is a common weak acid that is used in biology and medicine. Acetic acid is highly toxic to microorganisms, with concentrations greater than $5 \mathrm{~g} / \mathrm{L}$ inhibiting microbial growth and metabolism (Trček et al. 2015). The main reason acetic acid is toxic to microorganisms is its 
ability to cross the cell membrane and enter cells. This increases intracellular acetic acid concentrations and disrupts some physiological functions of the cell membrane (Conner and Kotrola 1995). There are large differences in acid resistance between different $\mathrm{AAB}$ species, with $K$. europaeus having high acid resistance and the ability to tolerate 15-20\% acetic acid (Andrés-Barrao et al. 2016). In contrast, $A$. aceti and A. pasteurianus, which are commonly used in acetic acid fermentation, can only tolerate 5-8\% acetic acid (Trček et al. 2007), while Saccharibacter and Asaia shows almost no growth in acetic acid-containing culture medium (Kommanee et al. 2011; Spitaels et al. 2013).

Acid resistance in AAB is intimately associated with cell structure and the levels of some enzymes in the cell membrane and cytoplasm. Acid resistance factors in Acetobacter and Komagataeibacter may be pyrroloquinoline quinone-dependent alcohol dehydrogenase (PQQ$\mathrm{ADH}$ ) and phospholipids on the cell membrane, proton motive force-dependent efflux pumps, $A B C$ transporter, and some enzymes and stress proteins in the TCA cycle (Nakano and Fukaya 2008). In addition, some AAB are able to change their morphology and form pellicles on the cell surface to increase acid resistance. QS systems, which are present in Komagataeibacter and Gluconacetobacter, provide new ideas for acid resistance mechanisms in $\mathrm{AAB}$ from the signaling pathway perspective.

\section{Acid resistance factors on the cell membrane Cell morphology and cell membrane composition}

Acetic acid has some effects on morphology in AAB. In the absence of acetic acid, K. europaeus appears as short rods. At an acetic acid concentration of $3 \%(\mathrm{v} / \mathrm{v})$, K. europaeus appears as long rods and small depressions appears at the cell membrane. As acetic acid concentration increases, $K$. europaeus forms longer and thinner rods (Trček et al. 2007). Changes in cell morphology decreases the effective area for passive diffusion of acetic acid into cells and the toxicity of acetic acid accumulation in microorganisms, enabling them to tolerate high acetic acid concentrations.

Acetobacter and Komagataeibacter are acetic acid-producing strains commonly used in industrial processes, but the latter has higher acid resistance than the former. Analysis of the glycolipid and phospholipid content in $K$. europaeus revealed that the glycolipid content increased by $67 \%$ in bacteria growing in $3 \%(\mathrm{v} / \mathrm{v})$ acetic acid culture medium compared with strains growing in culture medium without acetic acid while total phospholipid content decreased by 16.3\% (Trček et al. 2007). Chemical analysis of cell membrane phospholipids revealed that the phosphatidylcholine (PC) content of Komagataeibacter was significantly higher than that of Acetobacter, while the phosphatidylethanolamine (PE) content was significantly lower than that of Acetobacter (Goto et al. 2000). As the acetic acid concentration increases, the proportion of $\mathrm{PC}$ in the cell membrane increases while the proportion of phosphatidylglycerol (PG) decreases (Higashide et al. 1996). By using the method of gene inactivation, it is proved that $\mathrm{PC}$ on the cell membrane is not only the main phospholipid component, but also an essential factor for high acid resistance in $A$. aceti (Hanada et al. 2001). A higher PC content and lower PE content are considered to be more favorable to the production of high concentrations of acetic acid.

When compared with other microorganisms, the cell membrane lipids of Komagataeibacter also contain high levels of carotenoids, particularly tetrahydroxybacteriohopane (THBH) (Matsushita et al. 2016). THBH is a characteristic component in the cell membranes of Zymomonas mobilis, and THBH content increases during alcohol fermentation (Hermans et al. 1991). The THBH content in the membrane lipid of $\mathrm{AAB}$ up to $25 \%$ and THBH contributes to the stabilization of cell membrane at high ethanol concentrations (Ebisuya 2015). Overexpression of squalene-hopen cyclase, which participates in the synthesis of THBH precursors, increased the acetic acid resistance of $A A B$ compared with the wildtype strain which confirms that THBH is related to the acetic acid resistance in AAB (Ebisuya 2015).

Furthermore, Acetobacter can be classified by cell morphology as $\mathrm{R}$ (when the cell surface is rough) or $\mathrm{S}$ (when the cell surface is smooth) (Deeraksa et al. 2005). Studies have shown that the $\mathrm{R}$ strain can produce more acetic acid and possess acetic acid further oxidation ability compared to the $\mathrm{S}$ strain. The acetic acid further oxidation capacity is considered to be an important presentation of acid resistance in $\mathrm{AAB}$, showing that the $A$. pasteurianus $\mathrm{R}$ strain has higher acid resistance than the $\mathrm{S}$ strain. In addition, the intracellular acetic acid/acetate content in the S strain is 3-4 times higher than that of the $\mathrm{R}$ strain, showing that acetic acid molecules can easily enter the cell membrane of the A. pasteurianus S strain due to absence of the pellicle (Kanchanarach et al. 2010). When the polE gene that is used for cell surface polysaccharide synthesis to confirm is deleted, the $\mathrm{R}$ strain has better resistance towards ethanol and acetic acid (Brandt et al. 2017). This is because the pellicle on the cell surface prevents the entry of acetic acid into cells and enables high concentration acetic acid fermentation.

\section{Enzyme activity level of pyrroloquinoline quinone-dependent alcohol dehydrogenase}

PQQ is an important coenzyme that is ubiquitous in Gram-negative bacteria, participates in electron transport and can increase resistance towards radiation, high 
acidity, high temperature, and other extreme environments in certain microorganisms (Rajpurohit et al. 2008). PQQ-ADH is the key enzyme responsible for synthesizing acetic acid from ethanol in AAB (Fig. 1a).

The PQQ-ADH activity in highly acidic $K$. europaeus cells is two times greater than that of $A$. pasteurianus (Rajpurohit et al. 2008). When the ADH gene is deleted in A. pasteurianus, acid resistance is lost (Chinnawirotpisan et al. 2003), indicating that ADH activity contributes directly to acid resistance (Trček et al. 2007, 2006; Xia et al. 2015). Analysis of the genome of A. pasteurianus Ab3 revealed that it contains many membrane-bound PQQ-ADH (Wang et al. 2015c). Integrated analysis of published $\mathrm{AAB}$ genomes demonstrated that there are significant species differences in the gene copy number of PQQ-ADH. Komagataeibacter contains the most genes encoding PQQ-ADH and ADH, and these genes are absent in some strains of Gluconobacter and Gluconacetobacter. In addition, PQQ-ADH differs among species. Specifically, $K$. europaeus 5P3 contains six copies, while this gene is absent from $K$. hansenii ATCC 23,769 and $K$. medellinensis NBRC 3288. The copy number of PQQ$\mathrm{ADH}$ in A. pasteurianus is relatively stable. Therefore, differences in the number of PQQ-ADH genes may be crucial to differences in acid productivity and acid resistance in different AAB strains (Wang et al. 2015a).

\section{ATP-binding cassette transporter}

ABC transporter, which is located on cell membranes, is responsible for the transport of intracellular and extracellular substances and is ubiquitous in animals, plants, and microorganisms (Lewis et al. 2012). Currently, eight subfamilies of the $A B C$ transporter superfamily have been identified based on amino acid sequences; namely, A, $B, C, D, E, F, G$, and H. Among these, the ABCA1 transporter, which participates in lipid transport and plays an important role in anti-atherosclerosis and promotion of cholesterol efflux in macrophages, is the most well studied (Lv et al. 2013).

A putative $\mathrm{ABC}$ transporter that affects acid resistance in $A$. aceti, is present on the cell membranes of $A$. aceti and is induced by acetic acid (Nakano et al. 2006) (Fig. 1e). Analysis of a series of proteins produced in $A$. aceti cell membranes and acetic acid by two-dimensional electrophoresis identified a $60 \mathrm{ku}$ protein that is sensitive to acetic acid, which was named AatA. Molecular biology analysis of AatA revealed that it has a length of 591 amino acids, contains an $\mathrm{ABC}$ sequence and an $\mathrm{ABC}$ marker signal sequence, and that it belongs to the type $B$ of ABC transporter subfamily (Linton and Higgins 1998). Comparison of Aat $\mathrm{A}$ and macrolide transporters that are used as antibiotic efflux pumps revealed that they possess a common structure, showing that AatA may have a similar function as the latter (Kanchanarach et al. 2010; Méndez and Salas 2001; Mullins et al. 2012).

Studies have shown that aatA-deletion mutants have decreased formic acid, acetic acid, propionic acid, and lactic acid resistance. Disruption or deletion of the region between the two $\mathrm{ABC}$ transporters was found to lead to decreased acid resistance (Olano et al. 1995). Additionally, acetic acid resistance was restored if the plasmid pABC101 containing the aatA gene was inserted into aatA deletion mutants and acid resistance in E.coli containing pABC101 increased (Olano et al. 1995). These findings confirmed that aat $\mathrm{A}$ is an $\mathrm{ABC}$ transporter that is associated with acid resistance in bacteria and may act as an efflux pump for acetic acid (Nakano et al. 2006).

Comparative genomic analysis demonstrated that Komagataeibacter species contains more genes encoding putative $\mathrm{ABC}$ transporter proteins than Acetobacter (K. oboediens 174Bp2 possess 93 genes while $A$. pasteurianus IFO 3283-32 possesses 21 genes) (Wang et al. 2015a). This correlation demonstrates that strains with a high number of putative $\mathrm{ABC}$ transporter genes have higher acid resistance than strains with low numbers of putative $\mathrm{ABC}$ transporter genes.

\section{Proton motive force-driven efflux pumps}

Studies of the acid resistance mechanisms in Acetobacter identified $A$. aceti that can adapt to high concentrations of acetic acid. The concentration of cytoplasmic acetic acid in this bacteria is significantly lower than that of $\mathrm{AAB}$ that cannot adapt to high concentrations of acetic acid. Some researchers speculate that the cell membrane may contain an efflux pump that can pump acetic acid from the cytoplasm out of the cell membrane (Fig. 1f).

To verify whether acetic acid efflux pumps are present in the cell membranes of AAB, Matsushita et al. (2005) employed isotope labeling to study the transport of acetic acid/acetate in intact $A$. aceti IFO 3283 cells and found that they possess an acetic acid efflux pump that is dependent on the proton motive force. In bacterial cells, acetic acid and two electrons are produced from ethanol under the action of ADH and ALDH (Matsushita et al. 2004; Nakayama 1961). The synthesized acetic acid undergoes passive transport from the periplasmic space, past the cell membrane into the cytoplasm. The synthesized electrons are then transported to the oxidase coenzyme to generate a proton motive force. By using the proton motive force, efflux pumps can pump intracellular acetic acid out of cells and prevent acetic acid accumulation from affecting the growth and metabolism of $A A B$, enabling them to tolerate a highly acidic environment.

This efflux pump does not act on ethanol and is vastly different from the classical ABC transporter Pdr12, which is used to transport acetic acid anions in yeast cells. 
Hence, this acetic acid efflux pump is a $\mathrm{H}^{+}$retrograde transporter and not an $\mathrm{ABC}$ transporter (Matsushita et al. 2005). The acetic acid pump pumps out protonated acetic acid to maintain a low acetic acid environment in AAB.

\section{Acid resistance factors in the cytoplasm Overexpression of certain enzymes in the tricarboxylic acid cycle}

A study found that AAB can oxidize acetic acid into carbon dioxide and water when the ethanol substrate in culture medium is exhausted to promote secondary growth (Matsushita et al. 2016). In this process, which is known as acetic acid assimilation, acetyl-CoA synthetase (acs) catalyzes the conversion of acetate to acetyl-CoA and citrate synthase (aarA). Acetyl-CoA then enters the TCA cycle, enabling the removal of acetic acid through the TCA cycle (Ramírez-Bahena et al. 2013) (Fig. 1b). A. aceti decreases the harmful effects of acetic acid accumulation through cytoplasm acidification, showing that the cytoplasm may possess substances that can adapt to an acidic environment.

Proteomics analysis of A. pasteurianus ( $4 \%(\mathrm{~W} / \mathrm{V}))$ and Komagataeibacter spp. $(>10 \%(\mathrm{~W} / \mathrm{V}))$ under acid stimulation revealed various proteins that play important roles in stress response, the tricarboxylic acid cycle, cell membrane modification, and outer membrane protein and cell morphology changes (Andrés-Barrao et al. 2012). Among these proteins, overexpression of enzymes involved in the tricarboxylic acid cycle, such as citrate synthase, isocitrate dehydrogenase, dihydrolipoamide dehydrogenase, succinate dehydrogenase, succinyl-CoA and CoA transferase (Andrés-Barrao et al. 2016), further confirmed the role of the TCA cycle in acid resistance in AAB.

To analyze the specific acetic acid resistance factors in the cytoplasm of $\mathrm{AAB}$, analysis of proteomes induced by acetic acid was performed to detect genes and enzymes related to acid resistance. The results revealed that three genes (aarA, aarB, and aarC) will affect acid resistance in $\mathrm{AAB}$ and deletion of all three genes causes acid resistance to disappear in A. aceti 1023 (Fukaya et al. 1990). CS activity was not found in aarA gene deletion mutants of $A$. aceti, but introduction of aarA-containing plasmids restored CS activity. These findings demonstrated that the aarA gene is citrate synthase, which is closely associated with acid resistance in $A$. aceti (Mullins et al. 2008). Deletion of the aarC gene in $A$. aceti decreases acetic acid resistance and utilization capacities, but these two functions are restored after introduction of the aarC gene. In the TCA cycle, aarC replaces succinyl-CoA synthetase and directly converts succinyl-CoA to acetyl-CoA. The appearance of the branch can decrease the cell's metabolic need for free CoA and regulate the effects of the
TCA cycle on cytoplasmic pH (Francois et al. 2006). It is speculated that the aarB gene encodes the TCA activator SixA (Mullins et al. 2008). When there is a need to decrease intracellular acetic acid concentrations, these three aar genes synergistically act together to form a complete cycle that is different from the conventional TCA cycle (Fukaya et al. 1993). Large amounts of a 100 $\mathrm{ku}$ protein were found in acetic acid-containing culture medium, and sequence analysis revealed that it may be aconitase. Aconitase-overexpressing A. aceti can produce high acetic acid concentrations and decrease the growth doubling time. Increased aconitase activity and acid resistance was also found to increase the acetic acid concentration by $25 \%$, which was a significant improvement in the fermentation productivity of acetic acid (Nakano et al. 2004).

The above studies confirmed that increasing the activity of one or more enzymes in the TCA cycle such as citrate synthase and aconitase will lead to rapid consumption of acetic acid or elimination of toxicity due to entry of acetic acid into the cytoplasm, causing intracellular acetic acid to be maintained at a low level and increasing acetic acid resistance.

\section{Heat stress proteins}

Universal stress mechanisms are regulated by stress proteins known as molecular chaperones or chaperone proteins. HSPs are typical stress proteins that ensure correct folding of synthesized proteins in adverse environments and prevent intracellular protein denaturation (Hartl and Hayer-Hartl 2002).

GroES/L and DnaK/J are two common universal stress protein systems in $\mathrm{AAB}$ that are able to respond to many types of adverse environments (Yukphan et al. 2009). The HSP GroEL is significantly upregulated in $A$. aceti during batch feeding and continuous fermentation (Steiner and Sauer 2001). The transcript level of the groESL gene in $A$. aceti IFO 3283 was upregulated by heat, ethanol, and acetic acid. Furthermore, intracellular overexpression of the groESL gene can increase resistance to the aforementioned factors, showing that the groESL gene is related to resistance to adverse environments in $\mathrm{AAB}$ (Okamoto-Kainuma et al. 2002). Overexpression corresponding genes of intracellular grpE and dnaKJ increased resistance towards the fermentation environment in $\mathrm{AAB}$ (Ishikawa et al. 2010; Okamoto-Kainuma et al. 2004). Employing two-dimensional electrophoresis to conduct a comprehensive study of intracellular protein levels in $A$. pasteurianus LMG $1262 \mathrm{~T}$ during acetic acid fermentation, it was found that fermentation increased the protein expression levels of GrpE, DnaK, DnaJ, GroES, GroEL, and $\mathrm{ClpB}$ to varying extents, with the expression level of GrpE being increased by 9.42 times compared with the 
early fermentation stage (Andrés-Barrao et al. 2012; Wu et al. 2017). Overall, the aforementioned studies showed that the universal stress mechanism mediated by HSPs is one of the ways by which $\mathrm{AAB}$ ensure smooth acetic acid fermentation (Fig. 1c).

\section{Other factors}

\section{Quorum sensing}

Quorum sensing (QS) refers to the spontaneous production and release of specific signaling molecules by microorganisms in response to changes in the environment and sensing of changes in the concentration of these molecules for cell-cell exchange, thereby regulating the population behavior of microorganisms (Papenfort and Bassler 2016). Known major signaling molecules include: $\mathrm{N}$-acyl-homoserine lactones (AHLs), autoinducer-2 (AI-2), diketopiperazines (DKPs), diffusible signal factors (DSFs), and 4-hydroxy-2-alkylquinolines (HAQs) (Mukherjee and Bassler 2019).

To date, QS in Pseudomonas aeruginosa, Staphylococcus aureus, Pseudomonas fluorescens, Streptococcus mutans, and Helicobacter pylori have been thoroughly investigated (Huang et al. 2009; Mukherjee et al. 2019; Rader et al. 2011; Wang et al. 2015b; Zhao et al. 2016), and studies have shown that QS plays important roles in biofilm formation, synthesis of virulence factors, and stress responses (Nickzad et al. 2015). However, research regarding QS in industrial microorganisms is relatively scant and has primarily focused on Lactobacillus (Maldonado-Barragán et al. 2009). The QS system has been found to be intimately associated with bacteriocin secretion and cathelicidin production during the growth of Lactobacillus. Additionally, QS plays an important role in cell morphology changes and changes in adhesion in response to adverse external environments (Kareb and Aïder 2019). Genome analysis studies have shown that certain $\mathrm{AAB}$ genomes possess homologous sequences that are similar to the luxI/luxR gene (luxI/luxR genes are usually homologues of ginI/ginR). Therefore, QS systems may play an important regulatory role in acid resistance, acid production, and growth of $\mathrm{AAB}$.

The first $A A B$ that was shown to possess a $Q S$ regulatory mechanism was $K$. intermedius, and Iida et al. (2008a) was the first to report the ginI/ginR QS system in $K$. intermedius. The ginI gene encodes an AHLs synthase and ginR encodes a signal sensor protein. Knocking out ginI or ginR genes can increase the growth rate of $A A B$ in ethanol-containing culture media as well as increase acetic acid and gluconic acid productivity and defoaming ability (Iida et al. 2008a). Further analysis also showed that GmpA, a protein from the OmpA family, is regulated by QS systems and that this protein plays an important role in inhibition of oxidative fermentation of acetic acid.
Moreover, GmpA is directly regulated by GinA, which is a protein with a length of 89 amino acids that is encoded by a gene located downstream of ginI (Iida et al. 2008b). This protein is unique to $A A B$ and its expression is regulated by QS. In addition, the GinA protein can regulate the expression of other genes, including gltA, pdeA, pdeB, and nagA (Iida et al. 2009) (Fig. 1d). The culture medium of Ga. diazotrophicus PAL5 was detected eight QS signal molecules and confirmed that this organism possesses a QS regulatory mechanism (Nieto-Peñalver et al. 2012). In addition, whole genome sequencing showed that this bacteria possesses many signaling pathway encoding genes, including $16 \mathrm{c}$-di-CMP synthases, 14 membrane-bound histidine kinase signaling protein encoding genes, as well as a set of complete luxI/luxR QS encoding genes (Bertalan et al. 2009; Bertini et al. 2014). Subsequently, a study found that some genes in $K$. xylinus CGMCC 2955 jointly regulate intracellular c-diGMP (a critical activator of the Bcs subunit) levels and confirmed the presence of the luxR gene (Liu et al. 2018). These findings demonstrate that QS is present in K. xylinus CGMCC 2955. Quenching of QS systems causes significant changes in the expression of intracellular and extracellular proteins, showing that QS systems may play an important role in population exchange, host colonization, and stress responses.

To date, QS regulatory mechanisms in AAB have only been found in Komagataeibacter and Gluconacetobacter and there have been no reports of QS in other species. This is because the genome data of many AAB are incomplete. Additionally, even though sequences homologous to $\mathrm{QS}$ encoding genes are present in the genomes of $\mathrm{AAB}$, the functions of these genes are mostly not annotated or they are hypothetical proteins. At the same time, the similarity of genes is low between different genera. Finally, $\mathrm{AAB}$ are highly variable, have unstable genomes, and different $\mathrm{AAB}$ may produce specific signaling molecules that cannot be detected based on existing detection methods. Although the potential correlation between QS system and other acid resistance mechanisms was proposed, there are still many processes that need more research to explain (Xia et al. 2017) (Fig. 2). In conclusion, QS research regarding Komagataeibacter and Gluconacetobacter has provided new data that will be useful for investigations of other AAB. With continuous improvements in $\mathrm{AAB}$ genomic data and annotation of new gene functions, signaling pathways regulated by acid resistance in AAB will be elucidated.

\section{Challenges and perspectives}

Although $A A B$ has long been used in vinegar fermentation, its incomplete oxidation characteristic has attracted increasing attraction owing to its potential 


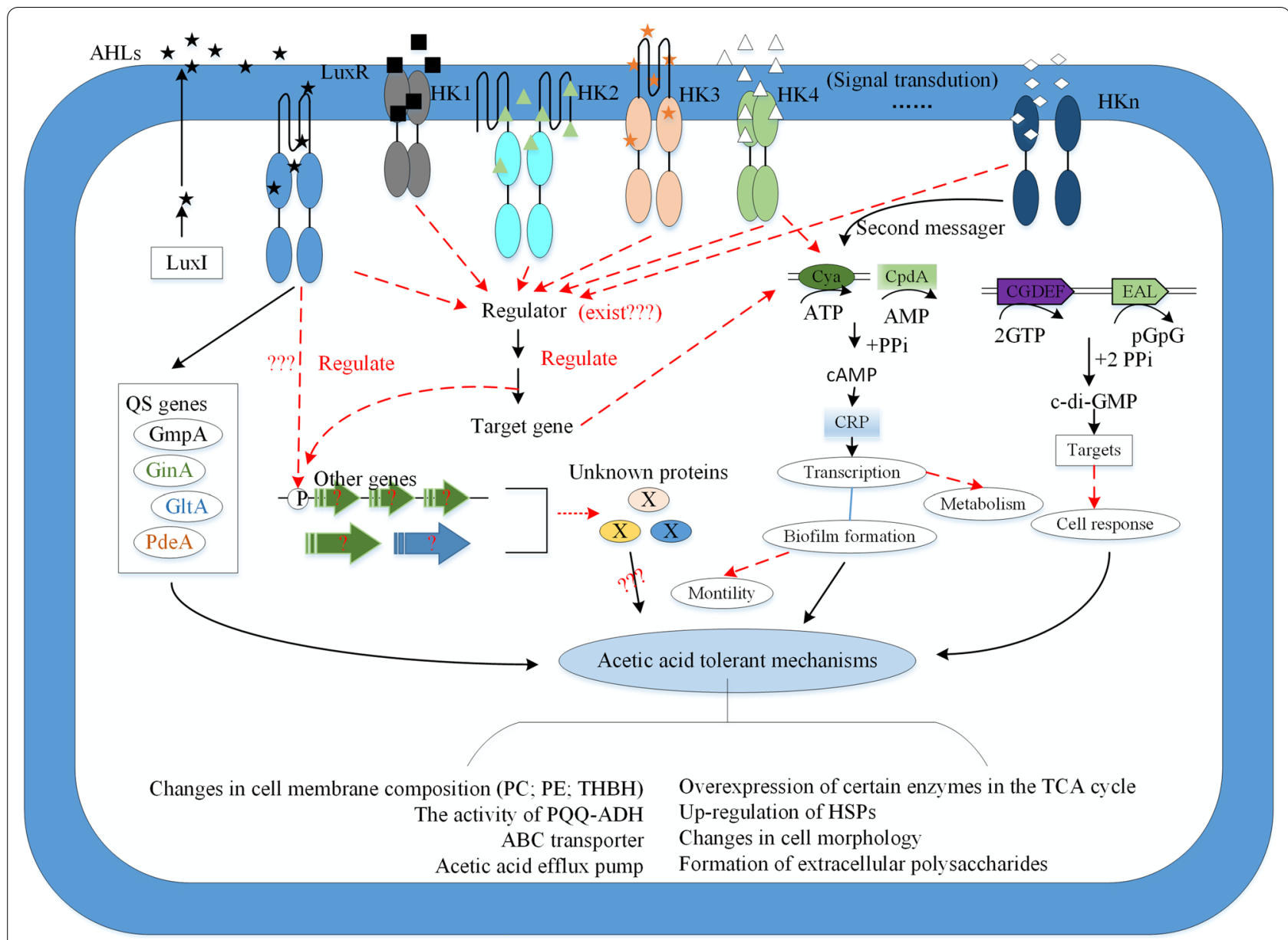

Fig. 2 The possible quorum sensing system model in Komagataeibacter and Gluconacetobacter. The red dotted line and "?" refer to the potential relationship or the process have not been identified. The abbreviation of HK refer to histidine kinase

in such applications as sugar alcohol oxidation, biofuel cells, and biosensors. Elucidation of acid resistance mechanisms in $\mathrm{AAB}$ is important to the selective breeding of $\mathrm{AAB}$ with high acid resistance and improving acetic acid fermentation processes. However, the acid resistance mechanisms in AAB are still not completely clear, as currently available data is insufficient for elucidation of the molecular mechanisms involved.

Too few proteins have been identified in proteomics to support global differential profile analysis, resulting in fragmentation and generalization of existing knowledge pertaining to acid resistance mechanisms. This poses challenges in construction of a complete pathway or process. In addition, further functional annotation of large amounts of unknown proteins is required. At the same time, the identification of low numbers of less abundant proteins, membrane proteins, and transcription factors also limits our understanding of how AAB respond to high acidity stress. Accordingly, further studies using more effective methods such as iTRAQ or MRM are needed.

QS systems provide new ideas for studying acid resistance mechanisms in $\mathrm{AAB}$ from a signaling pathway perspective. However, QS research regarding AAB is mainly focused on Komagataeibacter and Gluconacetobacter, and their intrinsic molecular regulatory mechanisms have not been fully studied. There is also an absence of studies confirming the distribution and regulatory pathways of QS in other $\mathrm{AAB}$ species. There are still many questions regarding the role of QS in regulating the physiological status of $\mathrm{AAB}$ and studies of genomics and metabolomics are needed (Fig. 2).

Other signaling pathways that are similar to the QS system, such as two-component systems and toxinantitoxin systems, have been widely described in other bacteria and are known to be the major signaling regulatory networks. The regulation of acetic acid fermentation and acid resistance mechanisms in AAB by these 


\section{other signaling pathways may be worth studying in the} future.

\section{Acknowledgements}

We would like to thank Let Pub organization for language assistance.

\section{Authors' contributions}

$\mathrm{HSH}$ and XMQ conceived and designed the overall frame of the article. XMQ proposed the article innovation. XMQ wrote the manuscript. $Y Z$ beautified the figures and revised the grammar of the manuscript. $Y Z$ provied some documents and sorted out the writing thoughts. All authors read and approved the final manuscript.

\section{Funding}

This work has been supported by the National High Technology Research and Development Program of China (2012AA021201).

\section{Availability of data and materials}

Not applicable.

\section{Ethics approval and consent to participate}

This article does not contain any studies with human participants or anmals performed by any of the authors. All authors read and approved the manuscript to be publicated.

\section{Competing interests}

The authors declare that they have no conflict of interest.

\section{Author details}

${ }^{1}$ College of Biotechnology and Pharmaceutical Engineering, Nanjing Tech University, No. 30, Puzhu Road, Nanjing 211800, China. ${ }^{2}$ National Engineering Technique Research Center for Biotechnology, Nanjing Tech University, No. 30, Puzhu Road, Nanjing 211800, China.

Received: 28 January 2021 Accepted: 4 February 2021

Published online: 17 February 2021

\section{References}

Andrés-Barrao C, Saad MM, Chappuis M-L, Boffa M, Perret X, Ortega Pérez R, Barja F (2012) Proteome analysis of Acetobacter pasteurianus during acetic acid fermentation. J Proteomics 75(6):1701-1717. https://doi. org/10.1016/j.jprot.2011.11.027

Andrés-Barrao C, Saad MM, Cabello Ferrete E, Bravo D, Chappuis M-L, Ortega Pérez R, Junier P, Perret X, Barja F (2016) Metaproteomics and ultrastructure characterization of Komagataeibacter spp. involved in high-acid spirit vinegar production. Food Microbiol 55:112-122. https://doi. org/10.1016/j.fm.2015.10.012

Asai T (1935) Taxonomic studies on acetic acid bacteria and allied oxidative bacteria isolated from fruits. A new classification of the oxidative bacteria. J Agric Chem Soci Japan 11:674-708

Azuma Y, Hosoyama A, Matsutani M, Furuya N, Horikawa H, Harada T, Hirakawa H, Kuhara S, Matsushita K, Fujita N, Shirai M (2009) Whole-genome analyses reveal genetic instability of Acetobacter pasteurianus. Nucleic Acids Res 37(17):5768-5783. https://doi.org/10.1093/nar/gkp612

Baek JH, Kim KH, Moon JY, Yeo SH, Jeon CO (2020) Acetobacter oryzoeni sp. nov., isolated from Korean rice wine vinegar. Int J Syst Evol Microbiol 70(3):2026-2033. https://doi.org/10.1099/ijsem.0.004008

Beijerinck MW (1898) Ueber die arten der essigbakterien. Zentralbl Bakteriol Parasitenkd Infektionskr Hyg Abt II 2(4):209-216

Bertalan M, Albano R, de Pádua V, Rouws L, Rojas C, Hemerly A, Teixeira K, Schwab S, Araujo J, Oliveira A, França L, Magalhães V, Alquéres S, Cardoso A, Almeida W, Loureiro M, Nogueira E, Cidade D, Oliveira D, Simão T, Macedo J, Valadão A, Dreschsel M, Freitas F, Vidal M, Guedes $\mathrm{H}$, Rodrigues E, Meneses C, Brioso P, Pozzer L, Figueiredo D, Montano $H$, Junior J, de Souza FG, Martin Quintana Flores V, Ferreira B, Branco A Gonzalez P, Guillobel H, Lemos M, Seibel L, Macedo J, Alves-Ferreira M, Sachetto-Martins G, Coelho A, Santos E, Amaral G, Neves A, Pacheco A, Carvalho D, Lery L, Bisch P, Rössle SC, Ürményi T, Rael Pereira A, Silva
R, Rondinelli E, von Krüger W, Martins O, Baldani J, Ferreira PCG (2009) Complete genome sequence of the sugarcane nitrogen-fixing endophyte Gluconacetobacter diazotrophicus Pal5. BMC Genomics 10(1):450. https://doi.org/10.1186/1471-2164-10-450

Bertini EV, Nieto Peñalver CG, Leguina AC, Irazusta VP, de Figueroa LIC (2014) Gluconacetobacter diazotrophicus PAL5 possesses an active quorum sensing regulatory system. Antonie Van Leeuwenhoek 106(3):497-506. https://doi.org/10.1007/s10482-014-0218-0

Brandt JU, Born FL, Jakob F, Vogel RF (2017) Environmentally triggered genomic plasticity and capsular polysaccharide formation are involved in increased ethanol and acetic acid tolerance in Kozakia baliensis NBRC 16680. BMC Microbiol 17(1):172. https://doi.org/10.1186/s1286 6-017-1070-y

Castro C, Cleenwerck I, Trček J, Zuluaga R, De Vos P, Caro G, Aguirre R, Putaux J, Gañán P (2013) Gluconacetobacter medellinensis sp. nov., celluloseand non-cellulose-producing acetic acid bacteria isolated from vinegar. Int J Syst Evol Microbiol 63(3):1119-1125. https://doi.org/10.1099/ ijs.0.043414-0

Chen Y, Bai Y, Li D, Wang C, Xu N, Hu Y (2017) Improvement of the flavor and quality of watermelon vinegar by high ethanol fermentation using ethanol-tolerant acetic acid bacteria. Int J Food Eng. https://doi. org/10.1515/ijfe-2016-0222

Chinnawirotpisan P, Theeragool G, Limtong S, Toyama H, Adachi OO, Matsushita K (2003) Quinoprotein alcohol dehydrogenase is involved in catabolic acetate production, while NAD-dependent alcohol dehydrogenase in ethanol assimilation in Acetobacter pasteurianus SKU1108. J Biosci Bioeng 96(6):564-571. https://doi.org/10.1016/s1389 $-1723(04) 70150-4$

Chouaia B, Gaiarsa S, Crotti E, Comandatore F, Degli Esposti M, Ricci I, Alma A, Favia G, Bandi C, Daffonchio D (2014) Acetic acid bacteria genomes reveal functional traits for adaptation to life in insect guts. Genome Biol Evol 6(4):912-920. https://doi.org/10.1093/gbe/evu062

Cleenwerck I, De Vos P (2008) Polyphasic taxonomy of acetic acid bacteria: An overview of the currently applied methodology. Int J Food Microbiol 125(1):2-14. https://doi.org/10.1016/j.ijfoodmicro.2007.04.017

Conner DE, Kotrola JS (1995) Growth and survival of Escherichia coli O157:H7 under acidic conditions. Appl Environ Microbiol 61(1):382-385. https:// doi.org/10.1128/AEM.61.1.382-385.1995

de Ory l, Romero LE, Cantero D (2002) Optimum starting-up protocol of a pilot plant scale acetifier for vinegar production. Int J Food Eng 52(1):31-37. https://doi.org/10.1016/S0260-8774(01)00082-6

de Ory l, Romero LE, Cantero D (2004) Operation in semi-continuous with a closed pilot plant scale acetifier for vinegar production. Int J Food Eng 63(1):39-45. https://doi.org/10.1016/s0260-8774(03)00280-2

Deeraksa A, Moonmangmee S, Toyama H, Yamada M, Adachi O, Matsushita K (2005) Characterization and spontaneous mutation of a novel gene, polE, involved in pellicle formation in Acetobacter tropicalis SKU1100. Microbiol 151(12):4111-4120. https://doi.org/10.1099/mic.0.28350-0

Dellaglio F, Cleenwerck I, Felis GE, Engelbeen K, Janssens D, Marzotto M (2005) Description of Gluconacetobacter swingsii sp. nov. and Gluconacetobacter rhaeticus sp. nov., isolated from Italian apple fruit. Int J Syst Evol Microbiol 55(6):2365-2370. https://doi.org/10.1099/ijs.0.63301-0

Drysdale GS, Fleet GH (1988) Acetic acid bacteria in winemaking: a review. Am J Enol Vitic 39(2):143-154

Dutta D, Gachhui R (2006) Novel nitrogen-fixing Acetobacter nitrogenifigens sp. nov., isolated from Kombucha tea. Int J Syst Evol Microbiol 56(8):18991903. https://doi.org/10.1099/ijs.0.64101-0

Ebisuya H (2015) Acetic acid tolerance in acetic acid bacteria. Japan J Lactic Acid Bacteria 26(2):118-123. https://doi.org/10.4109/jslab.26.118

Ferrer S, Mañes-Lázaro R, Benavent-Gil Y, Yépez A, Pardo I (2016) Acetobacter musti sp. nov., isolated from Bobal grape must. Int J Syst Evol Microbiol 66(2):957-961. https://doi.org/10.1099/ijsem.0.000818

Francois JA, Starks CM, Sivanuntakorn S, Jiang H, Ransome AE, Nam JW, Constantine CZ, KappockTJ (2006) Structure of a NADH-insensitive hexameric citrate synthase that resists acid inactivation. Biochem 45(45):13487-13499. https://doi.org/10.1021/bi061083k

Franke IH, Fegan M, Hayward C, Leonard G, Stackebrandt E, Sly LI (1999) Description of Gluconacetobacter sacchari sp. nov. a new species of acetic acid bacterium isolated from the leaf sheath of sugar cane and from the pink sugar-cane mealy bug. Int J Syst Bacteriol 49(4):1681-1693. https://doi.org/10.1099/00207713-49-4-1681 
Fukaya M, Takemura H, Okumura H, Kawamura Y, Horinouchi S, Beppu T (1990) Cloning of genes responsible for acetic acid resistance in Acetobacter aceti. J Bacteriol 172(4):2096-2104. https://doi.org/10.1128/ jb.172.4.2096-2104.1990

Fukaya M, Takemura H, Tayama K, Okumura H, Kawamura Y, Horinouchi S, Beppu T (1993) The aarC gene responsible for acetic acid assimilation confers acetic acid resistance on Acetobacter aceti. J Fermen Bioeng 76(4):270-275. https://doi.org/10.1016/0922-338X(93)90192-B

Goto H, Masuko M, Ohnishi M, Tsukamoto Y (2000) Comparative analysis of phospholipids for two acetobacters producing acetic acid at high and moderate concentrations. J Japan Oil Chem Soci 49(4):349-355. https:// doi.org/10.5650/jos1996.49.349

Greenberg DE, Porcella SF, Stock F, Wong A, Conville PS, Murray PR, Holland SM, Zelazny AM (2006) Granulibacter bethesdensis gen nov, sp. nov., a distinctive pathogenic acetic acid bacterium in the family Acetobacteraceae. Int J Syst Evol Microbiol 56(11):2609-2616. https://doi. org/10.1099/ijs.0.64412-0

Gullo M, Verzelloni E, Canonico M (2014) Aerobic submerged fermentation by acetic acid bacteria for vinegar production: Process and biotechnological aspects. Process Biochem 49(10):1571-1579. https://doi. org/10.1016/j.procbio.2014.07.003

Hanada T, Kashima Y, Kosugi A, Koizumi Y, Yanagida F, Udaka S (2001) A gene encoding phosphatidylethanolamine $\mathrm{N}$-methyltransferase from Acetobacter aceti and some properties of its disruptant. Biosci Biotech Biochem 65(12):2741-2748. https://doi.org/10.1271/bbb.65.2741

Hartl FU, Hayer-Hartl M (2002) Molecular chaperones in the cytosol: from nascent chain to folded protein. Science 295(5561):1852-1858. https:// doi.org/10.1126/science.1068408

Hermans MA, Neuss B, Sahm H (1991) Content and composition of hopanoids in Zymomonas mobilis under various growth conditions. J Bacteriol 173(17):5592-5595. https://doi.org/10.1128/jb.173.17.5592-5595.1991

Higashide T, Okumura H, Kawamura Y, Teranishi K, Hisamatsu M, Yamada T (1996) Membrane components and cell form of Acetobactor polyoxogenes (Vinegar Producing Strain) under high acidic conditions. Nippon Shokuhin Kogyo Gakkaishi 43(2):117-123. https://doi.org/10.3136/ nskkk.43.117

Hong H, Zhao M, Dou B, Luo H, Jiang K (2016) Fermentation preparation method of improved liquid flavor vinegar. China Patent CN106167756A, November 30, 2016

Hong H, Zhao M, Luo H, Dou B (2017) Optimization of Self-Suction SemiContinuous Vinegar Fermentation for Flavor Improvement. Food Sci 38(2):75-81. https://doi.org/10.7506/spkx1002-6630-201702012

Huang Z, Meric G, Liu Z, Ma R, Tang Z, Lejeune P (2009) luxS-Based Quorumsensing signaling affects biofilm formation in Streptococcus mutans. J Mol Microbiol Biotechnol 17(1):12-19. https://doi.org/10.1159/00015 9193

lida A, Ohnishi Y, Horinouchi S (2008a) Control of acetic acid fermentation by quorum Ssensing via N-acylhomoserine lactones in Gluconacetobacter intermedius. J Bacteriol 190(7):2546-2555. https://doi.org/10.1128/ jb.01698-07

lida A, Ohnishi Y, Horinouchi S (2008b) An OmpA family protein, a target of the Ginl/GinR quorum-sensing system in Gluconacetobacter intermedius, controls acetic acid fermentation. J Bacteriol 190(14):5009-5019. https ://doi.org/10.1128/jb.00378-08

lida A, Ohnishi Y, Horinouchi S (2009) Identification and characterization of target genes of the Ginl/GinR quorum-sensing system in Gluconacetobacter intermedius. Microbiol 155(9):3021-3032. https://doi.org/10.1099/ mic.0.028613-0

lino T, Suzuki R, Kosako Y, Ohkuma M, Komagata K, Uchimura T (2012) Acetobacter okinawensis sp. nov., Acetobacter papayae sp. nov., and Acetobacter persicus sp. nov.; novel acetic acid bacteria isolated from stems of sugarcane, fruits, and a flower in Japan. J Gen Appl Microbiol 58(3):235-243. https://doi.org/10.2323/jgam.58.235

Illeghems K, De Vuyst L, Weckx S (2013) Complete genome sequence and comparative analysis of Acetobacter pasteurianus 386B, a strain welladapted to the cocoa bean fermentation ecosystem. BMC Genomics 14(1):526. https://doi.org/10.1186/1471-2164-14-526

Ishikawa M, Okamoto-Kainuma A, Jochi T, Suzuki I, Matsui K, Kaga T, Koizumi Y (2010) Cloning and characterization of grpE in Acetobacter pasteurianus NBRC 3283. J Biosci Bioeng 109(1):25-31. https://doi.org/10.1016/j.jbios c.2009.07.008
Jojima Y, Mihara Y, Suzuki S, Yokozeki K, Yamanaka S, Fudou R (2004) Saccharibacter floricola gen nov, sp. nov., a novel osmophilic acetic acid bacterium isolated from pollen. Int J Syst Evol Microbiol 54(6):2263-2267. https://doi.org/10.1099/ijs.0.02911-0

Kanchanarach W, Theeragool G, Inoue T, Yakushi T, Adachi O, Matsushita K (2010) Acetic Acid Fermentation of Acetobacter pasteurianus: Relationship between Acetic Acid Resistance and Pellicle Polysaccharide Formation. Biosci Biotech Biochem 74(8):1591-1597. https://doi.org/10.1271/ bbb.100183

Kareb O, Aïder M (2019) Quorum sensing circuits in the communicating mechanisms of bacteria and its implication in the biosynthesis of bacteriocins by lactic acid bacteria: a review. Probiotics Antimicrob Proteins 12(1):5-17. https://doi.org/10.1007/s12602-019-09555-4

Katsura K, Kawasaki H, Potacharoen W, Saono S, Seki T, Yamada Y, Uchimura T, Komagata K (2001) Asaia siamensis sp. nov., an acetic acid bacterium in the a-Proteobacteria. Int J Syst Evol Microbiol 51(2):559-563. https://doi. org/10.1099/00207713-51-2-559

Kersters K, Lisdiyanti P, Komagata K, Swings J (2006) The family Acetobacteraceae: The genera Acetobacter, Acidomonas, Asaia, Gluconacetobacter, Gluconobacter, and Kozakia. The Prokaryotes 5:163-200. https://doi. org/10.1007/0-387-30745-1_9

Kim EK, Kim SH, Nam HJ, Choi MK, Lee KA, Choi SH, Seo YY, You H, Kim B, Lee WJ (2012) Draft genome sequence of Commensalibacter intestini A911T, a symbiotic bacterium isolated from drosophila melanogaster Intestine. J Bacteriol 194(5):1246. https://doi.org/10.1128/jb.06669-11

Kim KH, Cho GY, Chun BH, Weckx S, Moon JY, Yeo SH, Jeon CO (2018) Acetobacter oryzifermentans sp. nov., isolated from Korean traditional vinegar and reclassification of the type strains of Acetobacter pasteurianus subsp ascendens (Henneberg1898) and Acetobacter pasteurianus subsp. paradoxus (Frateur1950) as Acetobacter ascendens sp. nov., comb nov. Syst Appl Microbiol 41(4):324-332 doi:https://doi.org/10.1016/j.syapm .2018.03.003

Kommanee J, Tanasupawat S, Yukphan P, Malimas T, Muramatsu Y, Nakagawa Y, Yamada Y (2010) Asaia spathodeae sp. nov., an acetic acid bacterium in the a-Proteobacteria. J Gen Appl Microbiol 56(1):81-87. https://doi. org/10.2323/jgam.56.81

Kommanee J, Tanasupawat S, Yukphan P, Malimas T, Muramatsu Y, Nakagawa Y, Yamada Y (2011) Gluconobacter nephelii sp. nov., an acetic acid bacterium in the class Alphaproteobacteria. Int J Syst Evol Microbiol 61(9):2117-2122. https://doi.org/10.1099/ijs.0.026385-0

Lewis VG, Ween MP, McDevitt CA (2012) The role of ATP-binding cassette transporters in bacterial pathogenicity. Protoplasma 249(4):919-942. https:// doi.org/10.1007/s00709-011-0360-8

Li L, Wieme A, Spitaels F, Balzarini T, Nunes OC, Manaia CM, Van Landschoot A, De Vuyst L, Cleenwerck I, Vandamme P (2014) Acetobacter sicerae sp. nov., isolated from cider and kefir, and identification of species of the genus Acetobacter by dnaK, groEL and rpoB sequence analysis. Int J Syst Evol Microbiol 64(7):2407-2415. https://doi.org/10.1099/ijs.0.058354-0

Linton KJ, Higgins CF (1998) The Escherichia coli ATP-binding cassette (ABC) proteins. Mol Microbiol 28(1):5-13. https://doi.org/10.104 6/j.1365-2958.1998.00764.x

Lisdiyanti P, Kawasaki H, Seki T, Yamada Y, Uchimura T, Komagata K (2000) Systematic study of the genus Acetobacter with descriptions of Acetobacter indonesiensis sp. nov.. Acetobacter tropicalis sp. nov.. Acetobacter orleanensis (Henneberg (1906) comb nov Acetobacter lovaniensis (Frateur 1950) comb nov and Acetobacter estunensis (Carr 1958) comb nov. J Gen Appl Microbiol 46(3):147-165. https://doi. org/10.2323/jgam.46.147

Lisdiyanti P, Kawasaki H, Seki T, Yamada Y, Uchimura T, Komagata K (2001) Identification of Acetobacter strains isolated from Indonesian sources, and proposals of Acetobacter syzygii sp. nov.., Acetobacter cibinongensis sp. nov., and Acetobacter orientalis sp. nov. J Gen Appl Microbiol 47(3):119-131. https://doi.org/10.1016/S0034-5288(97)90015-1

Lisdiyanti P, Navarro RR, Uchimura T, Komagata K (2006) Reclassification of Gluconacetobacter hansenii strains and proposals of Gluconacetobacter saccharivorans sp. nov. and Gluconacetobacter nataicola sp. nov. Int J Syst Evol Microbiol 56(9):2101-2111. https://doi.org/10.1099/ijs.0.63252 $-0$

Liu M, Liu L, Jia S, Li S, Zou Y, Zhong C (2018) Complete genome analysis of Gluconacetobacter xylinus CGMCC 2955 for elucidating bacterial 
cellulose biosynthesis and metabolic regulation. Sci Rep 8(1):6266. https://doi.org/10.1038/s41598-018-24559-w

López-Garzón CS, Straathof AJJ (2014) Recovery of carboxylic acids produced by fermentation. Biotechnol Adv 32(5):873-904. https://doi. org/10.1016/j.biotechadv.2014.04.002

Lv YC, Yin K, Fu YC, Zhang DW, Chen WJ, Tang CK (2013) Posttranscriptional Regulation of ATP-Binding Cassette Transporter A1 in Lipid Metabolism. DNA Cell Biol 32(7):348-358. https://doi.org/10.1089/dna.2012.1940

Lynch KM, Zannini E, Wilkinson S, Daenen L, Arendt EK (2019) Physiology of Acetic Acid Bacteria and Their Role in Vinegar and Fermented Beverages. Compr Rev Food Sci F 18(3):587-625. https://doi. org/10.1111/1541-4337.12440

Maldonado-Barragán A, Ruiz-Barba JL, Jiménez-Díaz R (2009) Knockout of three-component regulatory systems reveals that the apparently constitutive plantaricin-production phenotype shown by Lactobacillus plantarum on solid medium is regulated via quorum sensing. Int J Food Microbiol 130(1):35-42. https://doi.org/10.1016/j.ijfoodmicr 0.2008 .12 .033

Malimas T, Yukphan P, Takahashi M, Kaneyasu M, Potacharoen W, Tanasupawat S, Nakagawa Y, Tanticharoen M, Yamada Y (2007) Gluconobacter kondonii sp. nov.., an acetic acid bacterium in the alpha-Proteobacteria. J Gen Appl Microbiol 53:301-307. https://doi.org/10.2323/jgam.53.301

Malimas T, Yukphan P, Takahashi M, Kaneyasu M, Potacharoen W, Tanasupawat S, Nakagawa Y, Tanticharoen M, Yamada Y (2008) Asaia lannaensissp. nov., a New Acetic Acid Bacterium in theAlphaproteobacteria. Biosci Biotech Biochem 72(3):666-671. https://doi.org/10.1271/bbb.70233

Malimas T, Yukphan P, Lundaa T, Muramatsu Y, Takahashi M, Kaneyasu M, Potacharoen W, Tanasupawat S, Nakagawa Y, Suzuki KI, Tanticharoen M, Yamada Y (2009) Gluconobacter kanchanaburiensis sp. nov., a brown pigment-producing acetic acid bacterium for Thai isolates in the Alphaproteobacteria. J Gen Appl Microbiol 55(3):247-254. https://doi. org/10.2323/jgam.55.247

Malimas T, Chaipitakchonlatarn W, Vu HTL, Yukphan P, Muramatsu Y, Tanasupawat S, Potacharoen W, Nakagawa Y, Tanticharoen M, Yamada Y (2013) Swingsia samuiensis gen nov, sp. nov., an osmotolerant acetic acid bacterium in the a-Proteobacteria. J Gen Appl Microbiol 59(5):375-384. https://doi.org/10.2323/jgam.59.375

Mas A, Torija MJ, García-Parrilla MDC, Troncoso AM (2014) Acetic Acid Bacteria and the Production and Quality of Wine Vinegar. Sci World J 2014:394671. https://doi.org/10.1155/2014/394671

Matsushita K, Toyama H, Adachi O (2004) Respiration in archaea and bacteria: diversity of prokaryotic respiratory systems. Springer, Dordrecht. https ://doi.org/10.1007/978-1-4020-3163-2

Matsushita K, Inoue T, Adachi O, Toyama H (2005) Acetobacter aceti possesses a proton motive force-dependent efflux system for acetic acid. J Bacteriol 187(13):4346-4352. https://doi.org/10.1128/jb.187.13.4346-4352.2005

Matsushita K, Toyama H, Tonouchi N, Okamoto-Kainuma A (2016) Acetic acid bacteria: ecology and physiology. Springer Nature, Japan

Matsutani M, Nishikura M, Saichana N, Hatano T, Masud-Tippayasak U, Theergool G, Yakushi T, Matsushita K (2013) Adaptive mutation of Acetobacter pasteurianus SKU1 108 enhances acetic acid fermentation ability at high temperature. J Biotechnol 165(2):109-119. https://doi.org/10.1016/j. jbiotec.2013.03.006

Méndez C, Salas JA (2001) The role of ABC transporters in antibiotic-producing organisms: drug secretion and resistance mechanisms. Res Microbiol 152(3-4):341-350. https://doi.org/10.1016/s0923-2508(01)01205-0

Millet V, Lonvaud-Funel A (2000) The viable but non-culturable state of wine micro-organisms during storage. Lett Appl Microbiol 30(2):136-141. https://doi.org/10.1046/j.1472-765x.2000.00684.x

Misra HS, Rajpurohit YS, Khairnar NP (2012) Pyrroloquinoline-quinone and its versatile roles in biological processes. J Biosci 37(2):313-325. https://doi. org/10.1007/s12038-012-9195-5

Mukherjee S, Bassler BL (2019) Bacterial quorum sensing in complex and dynamically changing environments. Nat Rev Microbiol 17(6):371-382. https://doi.org/10.1038/s41579-019-0186-5

Mullins EA, Francois JA, Kappock TJ (2008) A specialized citric acid cycle requiring succinyl-coenzyme A (CoA): acetate CoA-transferase (AarC) confers acetic acid resistance on the Acidophile Acetobacter aceti. J Bacteriol 190(14):4933-4940. https://doi.org/10.1128/jb.00405-08

Mullins EA, Starks CM, Francois JA, Sael L, Kihara D, KappockTJ (2012) Formylcoenzyme A (COA):oxalate CoA-transferase from the acidophile
Acetobacter aceti has a distinctive electrostatic surface and inherent acid stability. Protein Sci 21(5):686-696. https://doi.org/10.1002/ pro.2054

Nakano S, Fukaya M, Horinouchi S (2004) Enhanced expression of aconitase raises acetic acid resistance in Acetobacter aceti. FEMS Microbiol Lett 235(2):315-322. https://doi.org/10.1016/j.femsle.2004.05.007

Nakano S, Fukaya M, Horinouchi S (2006) Putative ABC transporter responsible for acetic acid resistance in Acetobacter aceti. Appl Environ Microbiol 72(1):497-505. https://doi.org/10.1128/aem.72.1.497-505.2006

Nakano S, Fukaya M (2008) Analysis of proteins responsive to acetic acid in Acetobacter: molecular mechanisms conferring acetic acid resistance in acetic acid bacteria. Int J Food Microbiol 125(1):54-59. https://doi. org/10.1016/j.ijfoodmicro.2007.05.015

Nakayama T (1961) Studies on acetic acid bacteria III purification and properties of coenzyme-independent aldehyde dehydrogenase. J Biochem 49(2):158-163. https://doi.org/10.1093/oxfordjournals.jbchem.a127273

Nanda K, Taniguchi M, Ujike S, Ishihara N, Mori H, Ono H, Murooka Y (2001) Characterization of acetic acid bacteria in traditional acetic acid fermentation of rice vinegar (Komesu) and unpolished rice vinegar (Kurosu) produced in Japan. Appl Environ Microbiol 67(2):986-990. https://doi. org/10.1128/aem.67.2.986-990.2001

Ndoye B, Cleenwerck I, Engelbeen K, Dubois-Dauphin R, Guiro AT, Van Trappen S, Willems A, Thonart P (2007) Acetobacter senegalensis sp. nov., a thermotolerant acetic acid bacterium isolated in Senegal (sub-Saharan Africa) from mango fruit (Mangifera indica L). Int J Syst Evol Microbiol 57(7):1576-1581. https://doi.org/10.1099/ijs.0.64678-0

Nickzad A, Lépine F, Déziel E (2015) Quorum sensing controls swarming motility of burkholderia glumae through regulation of rhamnolipids. PLOS ONE 10(6):e0128509. https://doi.org/10.1371/journal.pone.0128509

Nieto-Peñalver CG, Bertini EV, de Figueroa LIC (2012) Identification of N-acyl homoserine lactones produced by Gluconacetobacter diazotrophicus PAL5 cultured in complex and synthetic media. Arch Microbiol 194(7):615-622. https://doi.org/10.1007/s00203-012-0794-1

Nishijima M, Tazato N, Handa Y, Tomita J, Kigawa R, Sano C, Sugiyama J (2013) Gluconacetobacter tumulisoli sp. nov., Gluconacetobacter takamatsuzukensis sp. nov. and Gluconacetobacter aggeris sp. nov., isolated from Takamatsuzuka Tumulus samples before and during the dismantling work in 2007. Int I Syst Evol Microbiol 63(1 1):3981-3988. https://doi. org/10.1099/ijs.0.051292-0

Okamoto-Kainuma A, Wang Y, Sachiko K, Kenji T, Yukimichi K, Fujiharu Y (2002) Cloning and characterization of groESL operon in Acetobacter aceti. J Biosci Bioeng 94(2):140-147. https://doi.org/10.1263/jbb.94.140

Okamoto-Kainuma A, Wang Y, Fukaya M, Tukamoto Y, Ishikawa M, Koizumi Y (2004) Cloning and characterization of the dnaKJ operon in Acetobacter aceti. J Biosci Bioeng 97(5):339-342. https://doi.org/10.1016/s1389 $-1723(04) 70216-9$

Olano C, Rodríguez AM, Méndez C, Salas JA (1995) A second ABC transporter is involved in oleandomycin resistance and its secretion by Streptomyces antibioticus. Mol Microbiol 16(2):333-343. https://doi. org/10.1111/j.1365-2958.1995.tb02305.x

Papenfort K, Bassler BL (2016) Quorum sensing signal-response systems in Gram-negative bacteria. Nat Rev Microbiol 14(9):576-588. https://doi. org/10.1038/nrmicro.2016.89

Qi Z, Yang H, Xia X, Xin Y, Zhang L, Wang W, Yu X (2013) A protocol for optimization vinegar fermentation according to the ratio of oxygen consumption versus acid yield. J Food Eng 116(2):304-309. https://doi. org/10.1016/j.ffoodeng.2012.12.029

Qi Z, Yang H, Xia X, Quan W, Wang W, Yu X (2014) Achieving high strength vinegar fermentation via regulating cellular growth status and aeration strategy. Process Biochem 49(7):1063-1070. https://doi.org/10.1016/j. procbio.2014.03.018

Rader BA, Wreden C, Hicks KG, Sweeney EG, Ottemann KM, Guillemin K (2011) Helicobacter pylori perceives the quorum-sensing molecule Al-2 as a chemorepellent via the chemoreceptor TlpB. Microbiol 157(9):24452455. https://doi.org/10.1099/mic.0.049353-0

Rajpurohit YS, Gopalakrishnan R, Misra HS (2008) Involvement of a protein kinase activity inducer in DNA double strand break repair and radioresistance of deinococcus radiodurans. J Bacteriol 190(11):3948-3954. https://doi.org/10.1128/jb.00026-08

Ramírez-Bahena MH, Tejedor C, Martín I, Velázquez E, Peix A (2013) Endobacter medicaginis gen nov, sp. nov., isolated from alfalfa nodules in an acidic 
soil. Int J Syst Evol Microbiol 63(5):1760-1765. https://doi.org/10.1099/ ijs.0.041368-0

Saichana N, Matsushita K, Adachi O, Frébort I, Frebortova J (2015) Acetic acid bacteria: A group of bacteria with versatile biotechnological applications. Biotechnol Adv 33(6):1260-1271. https://doi.org/10.1016/j.biote chadv.2014.12.001

Sainz F, Navarro D, Mateo E, Torija MJ, Mas A (2016) Comparison of d-gluconic acid production in selected strains of acetic acid bacteria. Int J Food Microbiol 222:40-47. https://doi.org/10.1016/j.ijfoodmicro.2016.01.015

Sengun IY, Karabiyikli S (2011) Importance of acetic acid bacteria in food industry. Food Control 22(5):647-656. https://doi.org/10.1016/j.foodc ont.2010.11.008

Sengun IY (2017) Acetic acid bacteria: fundamentals and food applications. CRC Press, Boca Raton, FL

Servin-Garciduenas LE, Sanchez-Quinto A, Martinez-Romero E (2014) Draft genome sequence of Commensalibacter papalotli MX01, a symbiont identified from the guts of overwintering monarch butterflies. Genome Announc 2(2):e00128-e1114. https://doi.org/10.1128/genomeA.00128 $-14$

Sievers M, Sellmer S, Teuber M (1992) Acetobacter europaeus sp. nov., a main component of industrial vinegar fermenters in central Europe. Syst Appl Microbiol 15(3):386-392. https://doi.org/10.1016/s0723-2020(11)80212 $-2$

Silva LR, Cleenwerck I, Rivas R, Swings J, Trujillo ME, Willems A, Velazquez E (2006) Acetobacter oeni sp. nov., isolated from spoiled red wine. Int J Syst Evol Microbiol 56(1):21-24. https://doi.org/10.1099/ijs.0.46000-0

Škraban J, Cleenwerck I, Vandamme P, Fanedl L, Trček J (2018) Genome sequences and description of novel exopolysaccharides producing species Komagataeibacter pomaceti sp. nov. and reclassification of Komagataeibacter kombuchae (Dutta and Gachhui 2007) Yamada et al. 2013 as a later heterotypic synonym of Komagataeibacter hansenii (Gosselé et al. 1983) Yamada et al. 2013. Syst Appl Microbiol 41(6):581-592. https://doi.org/10.1016/.syapm.2018.08.006

Slapšak N, Cleenwerck I, De Vos P, Trček J (2013) Gluconacetobacter maltaceti sp. nov., a novel vinegar producing acetic acid bacterium. Syst Appl Microbiol 36(1):17-21. https://doi.org/10.1016/j.syapm.2012.11.001

Soemphol W, Deeraksa A, Matsutani M, Yakushi T, Toyama H, Adachi O, Yamada M, Matsushita K (2011) Global analysis of the genes involved in the thermotolerance mechanism of thermotolerant Acetobacter tropicalis SKU1100. Biosci Biotech Biochem 75(10):1921-1928. https://doi. org/10.1271/bbb.110310

Sokollek SJ, Hertel C, Hammes WP (1998) Description of Acetobacter oboediens sp. nov. and Acetobacter pomorum sp. nov. two new species isolated from industrial vinegar fermentations. Int J Syst Bacteriol 48(3):935-940. https://doi.org/10.1099/00207713-48-3-935

Song NE, Cho SH, Baik SH (2016) Microbial community, and biochemical and physiological properties of Korean traditional black raspberry (Robus coreanus Miquel) vinegar. J Sci Food Agric 96(11):3723-3730. https:// doi.org/10.1002/jsfa.7560

Spitaels F, Li L, Wieme A, Balzarini T, Cleenwerck I, Van Landschoot A, De Vuyst L, Vandamme P (2013) Acetobacter lambici sp. nov., isolated from fermenting lambic beer. Int J Syst Evol Microbiol 64(4):1083-1089. https ://doi.org/10.1099/ijs.0.057315-0

Steiner P, Sauer U (2001) Proteins induced during adaptation of Acetobacter aceti to high acetate concentrations. Appl Environ Microbiol 67(12):5474-5481. https://doi.org/10.1128/aem.67.12.5474-5481.2001

Suzuki R, Zhang Y, lino T, Kosako Y, Komagata K, Uchimura T (2010) Asaia astilbes sp. nov., Asaia platycodi sp. nov., and Asaia prunellae sp. nov., novel acetic acid bacteria isolated from flowers in Japan. J Gen Appl Microbiol 56(4):339-346. https://doi.org/10.2323/jgam.56.339

Tanasupawat S, Kommanee J, Yukphan P, Muramatsu Y, Nakagawa Y, Yamada $Y$ (2001) Acetobacter farinalis sp. nov., an acetic acid bacterium in the a-Proteobacteria. J Gen Appl Microbiol 51(2):559-563. https://doi. org/10.2323/jgam.57.159

Tanasupawat S, Kommanee J, Yukphan P, Moonmangmee D, Muramatsu Y, Nakagawa Y, Yamada Y (2011) Gluconobacter uchimurae sp. nov., an acetic acid bacterium in the $a$-Proteobacteria. J Gen Appl Microbiol 57(5):293-301. https://doi.org/10.2323/jgam.57.293

Tesfaye W, Morales ML (2002) Wine vinegar: technology, authenticity and quality evaluation. Trends Food Sci Technol 13(1):12-21. https://doi. org/10.1016/S0924-2244(02)00023-7
Trček J, Barja F (2015) Updates on quick identification of acetic acid bacteria with a focus on the 16S-23S rRNA gene internal transcribed spacer and the analysis of cell proteins by MALDI-TOF mass spectrometry. Int J Food Microbiol 196:137-144. https://doi.org/10.1016/j.jffoodmicr 0.2014 .12 .003

Trček J, Raspor P, Teuber M (2000) Molecular identification of Acetobacter isolates from submerged vinegar production, sequence analysis of plasmid pJK2-1 and application in the development of a cloning vector. Appl Microbiol Biotechnol 53(3):289-295. https://doi.org/10.1007/ s002530050023

Trček J, Toyama H, Czuba J, Misiewicz A, Matsushita K (2006) Correlation between acetic acid resistance and characteristics of PQQ-dependent ADH in acetic acid bacteria. Appl Microbiol Biotechnol 70(3):366-373. https://doi.org/10.1007/s00253-005-0073-z

Trček J, Jernejc K, Matsushita K (2007) The highly tolerant acetic acid bacterium Gluconacetobacter europaeus adapts to the presence of acetic acid by changes in lipid composition, morphological properties and PQQdependent ADH expression. Extremophiles 11(4):627-635. https://doi. org/10.1007/s00792-007-0077-y

Trček J, Mira NP, Jarboe LR (2015) Adaptation and tolerance of bacteria against acetic acid. Appl Microbiol Biotechnol 99(15):6215-6229. https://doi. org/10.1007/s00253-015-6762-3

Vu HTL, Yukphan P, Chaipitakchonlatarn W, Malimas T, Muramatsu Y, Bui UTT, Tanasupawat S, Duong KC, Nakagawa Y, Pham HT, Yamada Y (2013) Nguyenibacter vanlangensis gen nov sp. nov. an unusual acetic acid bacterium in the a-Proteobacteria. J Gen Appl Microbiol 59(2):153-166. https://doi.org/10.2323/jgam.59.2_153

Wang B, Shao Y, Chen T, Chen W, Chen F (2015a) Global insights into acetic acid resistance mechanisms and genetic stability of Acetobacter pasteurianus strains by comparative genomics. Sci Rep 5(1):18330. https://doi. org/10.1038/srep18330

Wang M, Schaefer AL, Dandekar AA, Greenberg EP (2015b) Quorum sensing and policing of Pseudomonas aeruginosa social cheaters. Proc Natl Acad Sci U S A 112(7):2187-2191. https://doi.org/10.1073/pnas.1500704112

Wang Z, Zang N, Shi J, Feng W, Liu Y, Liang X (2015c) Comparative Proteome of Acetobacter pasteurianus Ab3 During the High Acidity Rice Vinegar Fermentation. Appl Biochem Biotechnol 177(8):1573-1588. https://doi. org/10.1007/s12010-015-1838-1

Wu JJ, Ma YK, Zhang FF, Chen FS (2012) Biodiversity of yeasts, lactic acid bacteria and acetic acid bacteria in the fermentation of "Shanxi aged vinegar", a traditional Chinese vinegar. Food Microbiol 30(1):289-297. https://doi. org/10.1016/j.fm.2011.08.010

Wu X, Yao H, Cao L, Zheng Z, Chen X, Zhang M, Wei Z, Cheng J, Jiang S, Pan L, Li X (2017) Improving acetic acid production by overexpressing PQQADH in Acetobacter pasteurianus. Front Microbiol 8:1713. https://doi. org/10.3389/fmicb.2017.01713

Xia X, Zhu X, Yang H, Xin Y, Wang W (2015) Enhancement of rice vinegar production by modified semi-continuous culture based on analysis of enzymatic kinetic. Eur Food Res Technol 241(4):479-485. https://doi. org/10.1007/s00217-015-2477-z

Xia K, Li Y, Sun J, Liang X (2016) Comparative Genomics of Acetobacterpasteurianus Ab3, an acetic acid Producing strain isolated from Chinese traditional rice vinegar meiguichu. PLoS ONE. https://doi.org/10.1371/ journal.pone.0162172

Xia K, Zhu JL, Liang XL (2017) Advances in acid resistant mechanism of acetic acid bacteria and related quorum sensing system. Acta Microbiologica Sinica 57(3):321-332

Yakushi T, Matsushita K (2010) Alcohol dehydrogenase of acetic acid bacteria: structure, mode of action, and applications in biotechnology. Appl Microbiol Biotechnol 86(5):1257-1265. https://doi.org/10.1007/s0025 3-010-2529-z

Yamada Y (1983) Acetobacter xylinus sp. nov., nom rev, for the celluloseforming and cellulose-less, acetate-oxidizing acetic acid bacteria with the Q-10 system. J Gen Appl Microbiol 29(5):417-420. https://doi. org/10.2323/jgam.29.417

Yamada Y, Hoshino Kl, Ishikawa T (1997) The phylogeny of acetic acid bacteria based on the partial sequences of 165 ribosomal RNA: the elevation of the subgenus Gluconoacetobacter to the generic level. Biosci Biotech Biochem 61(8):1244-1251. https://doi.org/10.1271/bbb.61.1244

Yamada Y, Katsura K, Kawasaki H, Widyastuti Y, Saono S, Seki T, Uchimura T, Komagata K (2000) Asaia bogorensis gen nov, sp. nov., an unusual 
acetic acid bacterium in the alpha-Proteobacteria. Int J Syst Evol Microbiol 50(2):823-829. https://doi.org/10.1099/00207713-50-2-823

Yamada Y, Yukphan P, Lan Vu HT, Muramatsu Y, Ochaikul D, Tanasupawat S, Nakagawa Y (2012) Description of Komagataeibacter gen nov, with proposals of new combinations (Acetobacteraceae). J Gen Appl Microbiol 58(5):397-404. https://doi.org/10.2323/jgam.58.397

Yukphan P, Potacharoen W, Tanasupawat S, Tanticharoen M, Yamada Y (2004) Asaia krungthepensis sp. nov., an acetic acid bacterium in the a-Proteobacteria. Int J Syst Evol Microbiol 54(2):313-316. https://doi. org/10.1099/ijs.0.02734-0

Yukphan P, Malimas T, Muramatsu Y, Takahashi M, Kaneyasu M, Tanasupawat S, Nakagawa Y, Suzuki K-I, Potacharoen W, Yamada Y (2008) Tanticharoenia sakaeratensisgen nov, sp. nov., a new osmotolerant acetic acid bacterium in the a-Proteobacteria. Biosci Biotech Biochem 72(3):672-676. https://doi.org/10.1271/bbb.70319

Yukphan P, Malimas T, Muramatsu Y, Takahashi M, Kaneyasu M, Potacharoen W, Tanasupawat S, Nakagawa Y, Hamana K, Tahara Y, Suzuki KI, Tanticharoen M, Yamada Y (2009) Ameyamaea chiangmaiensisgen nov, sp. nov., an Acetic Acid Bacterium in the a-Proteobacteria. Biosci Biotech Biochem 73(10):2156-2162. https://doi.org/10.1271/bbb.90070

Yukphan P, Malimas T, Muramatsu Y, Potacharoen W, Tanasupawat S, Nakagawa Y, Tanticharoen M, Yamada Y (2011) Neokomagataea gen nov, with descriptions of Neokomagataea thailandica sp. nov. and Neokomagataea tanensis sp. nov., osmotolerant acetic acid bacteria of the
a-Proteobacteria. Biosci Biotech Biochem 75(3):419-426. https://doi. org/10.1271/bbb.100344

Yun JH, Lee JY, Hyun DW, Jung MJ, Bae JW (2017) Bombella apis sp. nov., an acetic acid bacterium isolated from the midgut of a honey bee. Int J Syst Evol Microbiol 67(7):2184-2188. https://doi.org/10.1099/ijsem 0.001921

Zhang H, Liu G, Zhang J, Bao J (2016) Fermentative production of high titer gluconic and xylonic acids from corn stover feedstock by Gluconobacter oxydans and techno-economic analysis. Bioresour Technol 219:123131. https://doi.org/10.1016/j.biortech.2016.07.068

Zhao A, Zhu J, Ye X, Ge Y, Li J (2016) Inhibition of biofilm development and spoilage potential of Shewanella baltica by quorum sensing signal in cell-free supernatant from Pseudomonas fluorescens. Int J Food Microbiol 230:73-80. https://doi.org/10.1016/j.ijfoodmicro.2016.04.015

Zheng Y, Chang Y, Xie S, Song J, Wang M (2018) Impacts of bioprocess engineering on product formation by Acetobacter pasteurianus. Appl Microbiol Biotechnol 102(6):2535-2541. https://doi.org/10.1007/s0025 3-018-8819-6

\section{Publisher's Note}

Springer Nature remains neutral with regard to jurisdictional claims in published maps and institutional affiliations.

\section{Submit your manuscript to a SpringerOpen ${ }^{\circ}$ journal and benefit from:}

- Convenient online submission

- Rigorous peer review

- Open access: articles freely available online

- High visibility within the field

- Retaining the copyright to your article

Submit your next manuscript at springeropen.com 